\title{
A Panel Data Analysis of Capital Structure Determinants: Empirical Results from Turkish Capital Market
}

\author{
Ali Bayrakdaroğlu ${ }^{1}$, İlhan Ege $^{2} \&$ Nusret Yazıcı ${ }^{3}$ \\ ${ }^{1}$ Faculty of Economic and Administrative Sciences, Muğla Sitkı Koçman University, Kötekli, Muğla, Turkey \\ ${ }^{2}$ Faculty of Economic and Administrative Sciences, Mersin University, Çiftlikköy Campus, Yenisehir, Mersin, \\ Turkey \\ ${ }^{3}$ Türkiye İş Kurumu, Bakanlıklar, Ankara, Turkey \\ Correspondence: Dr. İlhan Ege, Faculty of Economic and Administrative Sciences, Mersin University, \\ Çiftlikköy Campus, 33343 Yenisehir, Mersin, Turkey. E-mail: ilhanege2005@hotmail.com
}

Received: January 15, 2013

Accepted: March 11, $2013 \quad$ Online Published: March 22, 2013

doi:10.5539/ijef.v5n4p131

URL: http://dx.doi.org/10.5539/ijef.v5n4p131

\begin{abstract}
The determinants of capital structure have been a widely discussed subject in the finance literature. The purpose of this paper is to determine whether firm-specific capital structure determinants in the emerging market of Turkey support the capital structure theories which were developed to explain the company structure in developed economies. Specifically, we try to answer the following questions: Firstly, are determinants of capital structure correlated with the leverage that has been declared in the developed economies setting correlated in Turkey as emerging market as well? And secondly are the modern capital structure theories (e.g. trade-off and pecking-order hypothesis) valid in explaining capital structure of the Turkish companies? In this paper, we apply econometric techniques and panel data analyses. We empirically examine the capital structure of 242 companies of different sectors that are traded in Istanbul Stock Exchange (ISE). In the period of 2000-2009 depending on the findings of the panel data analysis, we can conclude that Turkish companies do not have debt ratio targets. We suggest that Turkish companies follow a hierarchical company structure. More specifically, we claim that trade-off theory is less successful than the pecking order hypothesis in explaining the capital structure of the Turkish companies. Therefore, Turkish companies are following pecking-order hypothesis in their debt behaviors.
\end{abstract}

Keywords: capital structure, panel data, market value, emerging markets, Istanbul Stock Exchange

\section{Introduction}

The determinants of capital structure have been a widely discussed subject in the finance literature. Over the last five decades, the ability of financial theory to explain capital structure decisions has progressed remarkably. Researches propose theoretical models to explain capital structure patterns across companies and countries, and to provide empirical support to application of these models for the real business world (Modigliani and Miller 1958, Jensen and Meckling 1976, Myers 1977, Harris and Raviv 1991). A great number of researchers focused on capital structure decisions of publicly traded companies in emerging countries (Delcoure 2007; Chen 2004).

The empirical researches on the capital structure decisions of companies, which first appeared in the 1980s (Marsh; 1982; Breadly et al., 1984; Friend and Lang, 1988) and have continued since then, are mostly based on data collected from developed markets (USA, Japan, Germany, U.K., France, Italy and Canada etc.). Some examples of these studies are Titman and Wessels (1988), Hodder and Senbet (1990), Harris and Raviv (1991), Rajan and Zingales (1995), Wald (1999), Graham and Harvey (2001), Ozkan (2001), Chui et al. (2002), Bevan and Danbolt (2002), Giannetti (2003), Bancel and Mittoo (2004), Hall et al. (2004, ), Song and Philippatos (2004), Gaud et al. (2005), Brounen et al. (2006), and Mahajan and Tartaroglu (2008). In addition, a few studies that considered emerging markets (Brazil, Mexico, China, India, South Korea, Jordan, Malaysia, Pakistan, Thailand, Turkey and Zimbabwe etc.) have been performed. For example, Booth et al. (2001) is a pioneering study on the capital structures of emerging markets. Other studies are: Chen (2004), Pandey (2001), Pandey et al. (2001), Annuar and Shamsher (1993) and Ariff (1998). In general, empirical studies have been in two different fields: the developed markets and the emerging markets. Because, the institutional structures of the companies in 
developed markets are different from the structures of those in the developing markets.

In this paper, we examine the changes in the capital structure of Turkish companies. The purpose of this paper is to determine whether firm-specific capital structure determinants in the emerging market of Turkey support the capital structure theories which were developed to explain the company structures in developed economies. In other words, the main motivation for this study is to highlight the role of firm characteristics and country-specific variables in determining capital structure. Specifically, we try to answer the following questions: Firstly, are determinants of capital structure correlated with leverage that have been declared in the Developed Economies setting correlated in Turkey as emerging market as well? And secondly are the modern capital structure theories (e.g. trade-off and pecking-order hypothesis) useful in explaining capital structure of the Turkish companies within the emerging markets?

In this paper, we apply econometric techniques and panel data analyses (Chen, 2004; Cheng and Shiu, 2007; Fattouh et al., 2005; Kovenock and Phillips, 1997; Menendez and Gomez, 2000). We empirically examine the capital structure of 242 companies of various sectors that are traded in Istanbul Stock Exchange (ISE). We analyzed the capital structure determinants for companies. Apparently, firm-specific factors correlated with capital structure in emerging markets are similarly correlated in developed economies. This result is consistent with Booth et al. (2001) and Pandey (2001). These findings showed that firm-specific factors are important in determining capital structure. Aside from the difference of firm-specific factors, there are other institutional differences like economic development, financial market-specific factors (creditor and shareholder rights, level of market development, development of financial intermediaries, and the efficacy of the legal system) and country-specific factors (gross domestic product, inflation, tax rate, and loan rate).

The remainder of the paper is organized as follows: In the next section, we provide an overview of theories of capital structure and also cover the measures of the leverage and firm- and country-specific determinants of capital structure. In Section 2, we give the data source and methodology. In Section 3, we present our empirical method. We discuss the empirical results of our study in Section 4. In Section 5, we give the general conclusions that can be drawn from the findings of the study and suggestions for future research.

\section{Data Source and Methodology}

This study aims to question the validity of the existing capital structure theories used to detect the factors that influence the individual factors on the capital structure of publicly traded companies and the capital structure decisions in Turkey, which is an emerging market. Our database consists of the panel data set of 242 companies for the period of 2000-2009. The panel data has been collected from the yearly financial tables of the companies. The tables of the companies were taken from İstanbul Stock Exchange (ISE). With the collected data, 2420 balanced panels were built.

The dependent variable in this study is the debt ratio. In literature, while some of the empirical studies used book leverage (Chakraborty, 2010; Chen, 2004; Fattouh et al., 2005), others used market leverage (Deesomsak et al., 2004; Huang and Song, 2006) as dependent variable. Book leverage is defined as the book value of total debt divided by the book value of total assets. Market leverage is defined as the book value of the total debt divided by the book value of total liabilities plus the market value of total equity. This study considers market value-equity.

There are three measures of leverage in the study. Market short-term debt ratio, Lev-s(mv), is defined as short-term debt divided by short-term plus market value of equity. Market long-term debt ratio, Lev-1 (mv), is defined as long-term debt divided by long-term debt plus market value of equity. Market total debt ratio, Lev-t(mv), is defined as total debt (short-term plus long-term) divided by total debt plus market value of equity. It should be noted that market book debt ratio (Lev-t(mv)) are used as the main measure of leverage, and the rest Lev-s(mv) and Lev-l (mv)) are employed for robustness checks.

Among the firm-specific determinants of capital structure, we discuss profitability, tangibility of assets, size, growth opportunities, and non-debt tax shields. Also, we take into consideration country-specific determinants (macro-economic factors) which are economic development, inflation and taxes. The variables used in this study and their measurements are largely adopted from existing literature. In other words, previous empirical findings in the context of developed and emerging studies guided the selection of independent variables.

Profitability (PRO): This study uses the ratio of earnings before interest tax depreciation amortization to the total assets. Tangibility of Assets (TAN): This study uses the ratio of tangible fixed assets to total assets. Firm Size (FS): We use the natural algorithm of total assets (Tang and Jang, 2007). Growth Opportunities (GO): In our study, we use the percentage rates of the total assets in years to measure growth opportunities. Non-Debt Tax 
Shields (NDTS): In this study, we use the ratio of yearly depreciation and amortization amount to total assets as a measure of NDTS, as defined by Ahmad et. Al (2011). Economic Development (ED): The logarithm of percentage change at the ratio of GDP per capita was used for this study as economic development variable which is also used by Cheng and Shiu (2007). Inflation (INF): In our research, average of Consumer Price Index and Producer Price Index was taken into consideration as of inflation rate and it is added to model by taking the natural logarithm.

Taxes (TAX): In this research, the corporate tax rate of the economy is taken into account as a measure of tax variable.

As Harris and Raviv (1991) argue, different measures of leverage can produce different results and also can affect the interpretation of the results. Rajan and Zingales (1995) and Both et al. (2001) point out that the determinants of capital structures are highly sensitive to choice of leverage. Thus, three different measures of leverage are employed in this study to examine the determinants of corporate capital structure.

Two different models are used to test the validity of capital structure theories in ISE. As mentioned before, market leverage is used in the models. The dependent variables calculated depending on the market values and dependent variables determinant on the capital structure are analysed in terms of the three models given below:

\section{Model-1 (Short Term Leverage):}

$$
L e v-s(m v)_{i t}=\beta_{0}+\beta_{I}(F S)+\beta_{2}(P R O)+\beta_{3}(T A N)+\beta_{4}(G O)+\beta_{5}(N D T S)+\beta_{6}(E D)+\beta_{7}(I N F)+\beta_{8}(T A X)+\alpha_{i t}
$$

\section{Model-2 (Long Term Leverage):}

$$
\text { Lev-l(mv })_{i t}=\beta_{0}+\beta_{1}(F S)+\beta_{2}(P R O)+\beta_{3}(T A N)+\beta_{4}(G O)+\beta_{5}(N D T S)+\beta_{6}(E D)+\beta_{7}(I N F)+\beta_{8}(T A X)+\alpha_{i t}
$$

\section{Model-3 (Total Leverage):}

$$
\operatorname{Lev}-\mathrm{t}(\mathrm{mv})_{i t}=\beta_{0}+\beta_{1}(F S)+\beta_{2}(P R O)+\beta_{3}(T A N)+\beta_{4}(G O)+\beta_{5}(N D T S)+\beta_{6}(E D)+\beta_{7}(I N F)+\beta_{8}(T A X)+\alpha_{i t}
$$

$\beta_{0}$ stands for model constant, $\beta_{\mathrm{i}}$ stands for the coefficiency of independent variables, i stands for the firm number $(\mathrm{N}=243), \mathrm{t}$ stands for the number of the years $(\mathrm{T}=10)$ and $\alpha_{\mathrm{it}}$ stands for the error term.

Since the models included in regression are analysed by panel data analysis, the problem of heteroscedasticity may occur. To test whether heteroscedasticity problems exists or not we ran the Lagrange Multiplier (LM) test. The heteroscedasticity in the error term was fixed by the use of White (1980) estimator. Maximum likelihood method was used to fix the problem of autocorrelation, namely detecting correlation between the sequential error effects.

\section{Panel Data Analysis}

In order to determine the firm-and country-specific factors of capital structure in the emerging markets we used panel data analysis as the econometric analysis technique. The panel data analysis can be defined as a technique which uses cross data of the time dimension to predict the economical relations (Greene, 2003). The panel data analysis uses the affects of time as much as it uses the affects of the cross sections (Wooldridge, 2002). Thus, the analysis makes use of the data which has both time dimension and cross section dimension. Among the reasons why this technique has been preferred over the other techniques is that the technique lets us to control the covert effects which may be related the parameters within the set-up capital structure model. Furthermore, we expect that modelling the financial data set such that it will have both the time dimension and the cross section dimension will lead us to more accurate results.

Panel data analysis is superior to time series analysis and the cross section analysis. First of all in the panel data analyses we do not encounter the problem of observation number deficiency which is common in time series and cross section analysis. That's because, the cross observations collected throughout a period are combined, thus, the number of observations increases (Sun and Parikh, 2001). Secondly, since panel data analysis diminishes the interaction between the variables the parameters will be more reliable (Hsiao, 1999). This enhances variation and flow of information. In addition to these, panel data analysis may be used to 133nalyse more complex models when compared to time series analysis and cross section analysis (Gujarati, 2003). Further advantages of panel data analysis can be named as follows (Baltagi, 2001 and Balestra, 1992): It prevents the data loss due to the collection. It reduces the number of multicollinearity problems. It displays higher degrees of significance.

By and large, the models formed to make premises using panel data analysis are based on assumptions on features of error terms and on the instability of coefficients. These models can supply statistical information among groups of variables and among time periods. The most common models of this kind are the fixed effects model and random effects model. 
The fixed effects model assumes that the coefficiencies are change among the units or among units and time. That is, the differences in the fixed effects determine the differences in behaviors of units, taking the slope coefficiencies as constant (Yaffee, 2003). The model considers the individual effects of the companies as a fixed effect (Greene, 2003). To prove the existence of effects, the fixed effects model, which is relatively easy to apply, tests the hypothesis that group-specific fixed effects are not equal to each other.

The random effects model was developed to overcome the loss of the degree of significance in the fixed effects model. The model accepts that constant coefficiencies among the units do not vary. This model, in which the individual effects of the companies are coincidental, assumes that the constant will be determined randomly in order to obtain unconsidered independent variables or the error. The model works on the basis of this assumption (Tunay, 2009).

The most common way to decide which panel data analysis should be used is the Specification Test. The test helps to determine which model would result in better premises. If the coefficiencies are irrelevant, the random effects model should be used. If they are relevant, the fixed effects model should be used (Hausman and Taylor, 1981).

\section{Empirical Analysis}

\subsection{Descriptive Statistics}

Descriptive statistics (mean and standart deviation) for the variables are given in Table 1. In Table 1 Panel-A, there is brief statistics about leverage ratios which are used as dependent variable in the study. When the summary statistics in the table are examined, in general, total debt included leverage ratios seems to be higher than leverage ratios which is calculated by short and long term debt ratios.

Table 1. Summary statistics for leverage and its determinants (2000-2009)

\begin{tabular}{llll}
\hline \multicolumn{2}{l}{ Panel-A: Dependent Variables } & & \\
\hline & Firm-year observations & Mean & Std.dev. \\
\hline Lev-s(mv) & 2178 & 0.287 & 0.221 \\
Lev-l (mv) & 2178 & 0.101 & 0.126 \\
Lev-t(mv) & 2178 & 0.394 & 0.264 \\
\hline Panel-B: Independent Variables & & \\
\hline \multicolumn{5}{r}{} & Firm-year observations & Mean & Std.dev. \\
\hline FS $(\log )$ & 2178 & 13.384 & 1.803 \\
PRO $(\%)$ & 2178 & 2.735 & 17.918 \\
TAN & 2178 & 0.311 & 0.235 \\
GO(\%) & 2178 & 39.24 & 140.077 \\
NDTS & 2178 & 0.071 & 0.643 \\
ED & 2178 & 0.048 & 0.597 \\
INF & 2178 & 0.093 & 2.765 \\
TAX & 2178 & 0.216 & 0.046 \\
\hline
\end{tabular}

This table presents descriptive statistics for the variables used in our models. The data are from the İstanbul Stock Exchange and the sample contains 243 Turkish firms listed on the İstanbul Stock Exchange for which we have ten years of data for the period 2000-2009. Lev-s(mv), is defined as short-term debt divided by short-term plus market value of equity; Lev-l (mv), is defined as long-term debt divided by long-term debt plus market value of equity; Lev-t(mv), is defined as total debt (short-term plus long-term) divided by total debt plus market value of equity. And then, FS, is the natural logarithm of total assets; PRO, is the ratio earnings before interest, taxes, depreciation and amortization to total assets; TAN, is measured by the ratio of net fixed assets to total assets; GO, is the growth rate in total assets; NDTS, is the ratio of annual depreciation expenses to total assets; ED is, percentage growth rate of GDP per capita was regarded. INF calculated by getting algorithms of average PPI and CPI. TAX calculated by annual corporate tax ratio.

Average Lev-t(mv) ratio is 0.39 and for Lev-s(mv) and Lev-l(mv) ratios are approximately and respectively 0.29 and 0.10 for the data set of 242 firm within the 10 years period. Chakraborty (2010) found a higher average ratio (0.75) for Lev-t(mv). Contrarily, Huang and Song (2006) found a lower average value (0.12) for Lev-t(mv). The largest value for dependent variable's standard deviation belongs to total leverage ratio $(0.26)$. That the total leverage ratio takes a larger value compared to the short and long term leverage ratios confirms the situation. 
Panel-B in Table 1 presents summary statistics of the dependent variables in the period of 2000-2009. The statistics given here are similar to those presented by Chakraborty (2010). In Panel-B, it is seen that FS average is 13.38 , profitability rate is $2.73 \%$ and that $31 \%$ of the assets is of fixed assets. Additionally the growth rate of the Turkish companies is $39 \%$ and external debt shield is of $\% 7$ in average. When we look at the macro economic variables, the average GDP per capita growth rate in the country is $4.8 \%$. Inflation rate is in a downward trend since the year of 2002 and is around $9.3 \%$. Also average corporation taxes are $21.6 \%$.

Table 2 below displays the correlation coefficiencies between the variables. It is clear that the dependent variables are related to each other. Correlation coefficient between Lev-s(bv) and Lev-s(mv) is 0.82 ; it is 0.81 between Lev-l(bv) and Lev-l(mv) and it is 0.78 between Lev-t(bv) and Lev-t(mv). As it is seen, short term debt has the highest relation coefficient. Similar findings were found in the studies of Huang and Song (2006).

Table 2. Correlation coefficients between variables and VIF coefficients

\begin{tabular}{|c|c|c|c|c|c|c|c|c|c|c|c|c|}
\hline Variables & Lev-s(mv) & Lev-l (mv) & Lev-t(mv) & FS & PRO & TAN & GO & NDTS & ED & INF & TAX & VIF \\
\hline Lev-s(mv) & 1.00 & & & & & & & & & & & - \\
\hline Lev-l (mv) & 0.07 & 1.00 & & & & & & & & & & - \\
\hline Lev-t(mv) & 0.86 & 0.53 & 1.00 & & & & & & & & & - \\
\hline FS & 0.13 & 0.25 & 0.24 & 1.00 & & & & & & & & 1.06 \\
\hline PRO & -0.27 & -0.14 & -0.31 & 0.10 & 1.00 & & & & & & & 1.04 \\
\hline TAN & -0.00 & 0.33 & 0.15 & 0.29 & -0.13 & 1.00 & & & & & & 1.07 \\
\hline GO & 0.09 & -0.04 & 0.06 & 0.03 & 0.09 & -0.07 & 1.00 & & & & & 1.01 \\
\hline NDTS & 0.06 & -0.00 & 0.04 & -0.03 & 0.03 & 0.03 & -0.02 & 1.00 & & & & 1.00 \\
\hline ED & -0.05 & -0.06 & -0.09 & 0.03 & -0.05 & -0.02 & 0.11 & 0.07 & 1.00 & & & 2.67 \\
\hline INF & -0.04 & -0.09 & -0.15 & 0.06 & -0.16 & 0.12 & -0.27 & 0.13 & -0.07 & 1.00 & & 3.55 \\
\hline TAX & 0.05 & 0.08 & 0.10 & 0.01 & 0.14 & -0.13 & -0.05 & 0.10 & 0.16 & 0.12 & 1.00 & 8.66 \\
\hline
\end{tabular}

This table presents descriptive statistics for the variables used in our models. The data are from the İstanbul Stock Exchange and the sample contains 243 Turkish firms listed on the İstanbul Stock Exchange for which we have ten years of data for the period 2000-2009. Lev-s(mv), is defined as short-term debt divided by short-term plus market value of equity; Lev-l (mv), is defined as long-term debt divided by long-term debt plus market value of equity; Lev-t(mv), is defined as total debt (short-term plus long-term) divided by total debt plus market value of equity. And then, FS, is the natural logarithm of total assets; PRO, is the ratio earnings before interest, taxes, depreciation and amortization to total assets; TAN, is measured by the ratio of net fixed assets to total assets; GO, is the growth rate in total assets; NDTS, is the ratio of annual depreciation expenses to total assets; ED is, percentage growth rate of GDP per capita was regarded. INF calculated by getting algorithms of average PPI and CPI. TAX calculated by annual corporate tax ratio.

When we look at the explanatory variables, there is a high relation between TAN and FS (with correlation coefficient 0.29 ). Also, especially with the variables of FS, PRO, INF and TAX have both positive and negative relation with leverage ratios. Because of higher correlation coefficients, it may cause to multicollinearity error problems between variables. Variance Inflation Factor-VIF was used to test this situation. According to tests, VIF values were less than 10 , so there was a not multicollinearity error problem between variables (Note 1). Therefore, all explanatory variables can be used in panel data set at the same time.

\subsection{Hausman Specification Test}

Hausman specification test has been used to determine which one of the alternative panel analysis methods (fixed effects model and random effects model) among the 3 panel regression models should be applied. With regard to this, $\mathrm{H}_{0}$ hypothesis claims that "random effects exist" and $\mathrm{H}_{1}$ hypothesis claims that "random effects do not exist". The results of the Hausman specification test for the 3 panel regression models are given in Table 3 .

Table 3. Hausman specification test results

\begin{tabular}{llll}
\hline Models & Chi-square statistic & Chi-square statistic degrees of freedom & P value \\
\hline Model-1 (short-term leverage) & 53.16 & 8 & 0.000 \\
Model-2 (long-term leverage) & 35.88 & 8 & 0.000 \\
Model-3 (total leverage) & 97.86 & 8 & 0.000 \\
\hline
\end{tabular}


The results presented in Table 3 show that $\mathrm{H}_{0}$ hypothesis is rejected for leverage models with the significance level of $1 \%$, thus not all of the individual effects in total leverage models are random, but are fixed. That is to say, the $\mathrm{H}_{1}$ hypothesis which says that fixed effects model is more effective than random effects model. Consequently, the panel data regression was analyzed by the fixed effects model in this study.

\subsection{Empirical Results}

In this section, we present and discuss the findings of the panel regression analysis of the models that question which capital structure theories are suitable and acceptable for the Turkish companies. The fixed effects analysis was used in the analysis of the model (Table 3).

Initially, leverage Lev-t(mv), the basic dependent variable of Model-3, is presented. Afterwards, we present the analysis of Model-1 and Model-2, which were set on the basis of market value of the equity and short term leverage and long term leverage. Table 4 shows the findings of analysis with the dependent variable of leverages (Lev-t(mv), Lev-l(mv) and Lev-t(mv)).

Table 4. Panel regressions results on total leverage for Turkish-listed companies

\begin{tabular}{|c|c|c|c|c|c|c|}
\hline \multirow{2}{*}{ Dependent variables } & \multicolumn{2}{|c|}{ (Model-1) Lev-s(mv) } & \multicolumn{2}{|c|}{ (Model-2) Lev-l(mv) } & \multicolumn{2}{|c|}{ (Model-3) Lev-t(mv) } \\
\hline & Coefficient & t-Statistic & Coefficient & t-Statistic & Coefficient & t-Statistic \\
\hline Intercept & 0.004 & $(0.036)$ & -0.284 & $5.016)^{*}$ & -0.3476 & $(-3.005)^{*}$ \\
\hline FS & 0.015 & $(4.654)^{*}$ & 0.0630 & $(5.224)^{*}$ & 0.0262 & $(9.876)^{*}$ \\
\hline PRO & -0.001 & $(-7.987)^{*}$ & 0.001 & $(0.036)$ & -0.0130 & $(-8.234)^{*}$ \\
\hline TAN & -0.076 & $(-4.001)^{*}$ & -0.154 & $(-7.102)^{*}$ & $-0,0036$ & $(-0.298)$ \\
\hline GO & 0.002 & $(0.077)^{*}$ & -0.001 & $(-0.654)$ & 0.001 & $(3.776) *$ \\
\hline NDTS & -0.014 & $(3.175)^{*}$ & 0.001 & $(0.023)$ & -0.008 & $(-1.002) * * *$ \\
\hline ED & -0.2654 & $(-2.8876)^{* * *}$ & -0.3540 & $(-3.8876)^{* *}$ & -0.5885 & $(-3.7765)^{* * *}$ \\
\hline INF & -0.0451 & $(-1.0942)^{* *}$ & -0.0582 & $(-1.2374)^{* * *}$ & -0.0656 & $(-0.4326)^{* *}$ \\
\hline TAX & 0.1076 & $(1.0853)$ & 0.1509 & $(1.8765)^{* * *}$ & 0.2786 & $(2.6540)^{*}$ \\
\hline No. of obs. & 2178 & & 2178 & & 2178 & \\
\hline Adj- $R^{2}$ & 0.68 & & 0.59 & & 0.73 & \\
\hline
\end{tabular}

This table presents OLS regression using panel data with fixed effect. The data are from the İstanbul Stock Exchange and the sample contains 243 Turkish firms listed on the İstanbul Stock Exchange for which we have ten years of data for the period 2000-2009. Lev-t(bv), is defined as total debt (short-term plus long-term)divided by total debt plus book value of equity. And then, book value of equity is replaced by market value of equity Lev-t(bv) become market total debt ratio (Lev-t(mv)). FS, is the natural logarithm of total assets; PRO, is the ratio earnings before interest, taxes, depreciation and amortization to total assets; TAN, is measured by the ratio of net fixed assets to total assets; GO, is the growth rate in total assets; NDTS, is the ratio of annual depreciation expenses to total assets. ED is, percentage growth rate of GDP per capita was regarded. INF calculated by getting algorithms of average PPI and CPI. TAX calculated by annual corporate tax ratio.

In Table 4, we see that there is a statistically significant positive relation between FS and leverage ratio calculated by the total debt ratio (Model-3). Findings of all of the regression models with FS variable are congruent with the theoretical and empirical expectations. With regard to this, we can claim that as the assets ratio gets bigger, the loan rates rise as well. In the analyses using different leverages (Model-1 and Model-2), we have found similar results. Accordingly, as FS gets bigger, the expectation of lowering the agency costs will drive the companies to undergo more debt, which makes a higher possibility for the small companies than for the big companies. This result is congruent with the expectations of the trade-off theory.

The findings of the panel regression analysis show that pecking order hypothesis is valid for the Turkish companies since the profitability is significantly negative, in parallel with theoretical expectations. In all of the models, except from Model-2, profitability is significant (Table 4). According to these findings, we can assert that the highly profitable Turkish companies prefer retained earnings as their funds, thus, their debt ratio is low. This may be even taken as a sign that shows the companies run lower risk of bankruptcy. In consequence, we can say that decrease in the debt ratio of the companies in the capital structure shows that equity value increases. Equivalently, we can argue that the increase in the equity value means that the Turkish companies are not very much eager to allocate the equity.

Most of the empirical studies report that asset structure has a positive effect on determining the capital structure. 
Contrarily, tests in our study (except for Model-3) have resulted in a significant but negative relationship between asset structure and leverage. The negative relationship between the leverage and asset structure does not approve the trade-off theory, which suggests that the companies with more fixed assets in the asset structure have high debt ratio. With regard to this, we can claim that Turkish companies do not own fixed assets to collateralize.

Pecking order hypothesis, which suggests that the companies with high growth opportunities would have higher debt ratio, assumes that the variable of growth and leverage are positively related. According to the regression models where the variables of growth and of leverage, we detected a positive relation between these two variables (except for Model-2). We have not recorded a significant relation between growth opportunities and long term leverage (Lev-l(mv)) for the Turkish companies. In the light of the results of the analysis of the other models (Model-1 and Model-3), which display significant relations, we can suggest that rapidly growing Turkish companies cannot meet their needs from the internal funds. That is why they prefer short-term debt. Therefore, the idea that the directors of the companies which grow in debt would undergo more debt was not approved. In conclusion we can say that our findings suggest evidence in favour of the pecking order hypothesis.

Contrary to the theoretical expectations, we detected a positive relationship between the NDTS and leverage. Among the models set up with three variables, Model-2 (representing long term leverage) did not present significant relation. To put in another way, we can say that amortization value of the assets is not taken in consideration in the case of long term debt. All of the other models, namely Model-3 and Model-1 show significant relations. We can argue that the amortization values are considered in the models which do not involve long term debt. These findings conflict with the trade-off theory which claims that the companies with high NDTS would have higher debt ratio.

When we look at the results of country specific variables, coefficient of ED variable is negative as expected in all models. These coefficients are all statistically meaningful in different levels. This situation shows that, when the economy grows firms are using equity instead of debt. In another definition, firms are financing their growth with equities. When we assume all variables are fixed, firms in the more GDP ratio countries are using less debt compared to the firms in the less GDP ratio countries. One of the other negative macroeconomic variable is INF. INF has negative and significant relation with capital structure. According to this, increase in the inflation ratio makes debt financing more costly, so firms are using less debt in the high inflation periods. According to results of our analysis, TAX is the most important variable from country specific variables in all models. TAX variable coefficient has statistically positive and significant relation with capital structure in all models except Model-1. Positive coefficient as expected shows that, firms are using more debt to get benefit of tax shield.

In general, our findings are in accordance with the theoretical expectations and previous empirical studies. In the basic model (Model-3) the variables of FS, GO, and NDTS are marked positively whereas the variables of PRO and TAN are marked negatively. By and large, the sub-models support the findings presented in Table 4.

\section{Conclusion}

In our study, we analyzed the effects of the variables such as FS, PRO, TAN, GO, NDTS, ED, INF and TAX on the capital structure using the panel data analysis. We set up three different models with the dependent variables of market value of equity. The findings were interpreted in terms of the theories which explain the capital structure or debt usage of the companies (namely trade-off theory and pecking order hypothesis). Although there is a wide range of studies questioning the capital structure of companies in the developed countries, it is not the case for companies in least-developed countries. That is why; our study may be regarded as a step to fill a gap in the literature with the findings that it presents on the capital structure preferences of the companies in the emerging stock market of Turkey.

Our study aims at defining which firm- and country-specific factors are determinants on the capital structure and which of the present company structure theories are explanatory for the emerging market of Turkey. The findings presented in our study are statistically significant for all of the variables (even if in different models). That is to say, FS, PRO, TAN, GO, NDTS, ED, INF and TAX explain the dependent variables. Depending on the findings of the panel data analysis, we conclude that Turkish companies do not have target debt ratio. We can suggest that Turkish companies follow a hierarchical company structure. More specifically, we claim that trade-off theory is less successful than the pecking order hypothesis in explaining the capital structure of the Turkish companies. Therefore, Turkish companies are following pecking-order hypothesis in their debt behaviors.

Specifically, we can say that bigger companies tend to have higher debt ratios when compared to the small companies. In addition we can suggest that profitable Turkish companies prefer less debt. The companies with 
large amounts of fixed assets tend to display lower debt ratios. The Turkish companies with high growth opportunities may have high debt ratios, contrary to the expectations. The Turkish companies with high NDTS may be asserted as willing to have high debt ratios. Also, Turkish companies choose to finance with equities in the periods of high inflation and high growth, whereas choose the debt financing in periods of high tax ratios to get benefits of tax shield.

In our study, we concentrated on the firm- and country-specific factor determinants on the company structure. In addition to these firm-specific factors, the special factors of financial market are considered to be relatively influential on the capital structure. The later factors have more importance in the emerging markets than they are in the economy of developed countries. In this regard, the capital structure decisions should be tested in terms of creditor and shareholder rights, level of market development, development of financial intermediaries, and the efficacy of the legal system. Testing the capital structure theories by taking all of these three different factors offers a promising research subject for the future studies.

\section{References}

Annuar, M. N., \& Shamsher, M. (1993). Capital Structure. Capital Market Review, 1(2), 171-177.

Ariff, M. (1998). Stock Pricing In Malaysia - Corporate Financial \& Investment Management. UPM Press.

Balestra, P. (1992). Introduction To Linear Models For Panel Data The Econometrics Of Panel Data Handbook Of Theory Abd Applications. L. Matyas \& P. Sevestre (Eds.). Kluwer Academic Publishers.

Baltagi, B. H. (2001). Econometric Analysis of Panel Data (2nd ed.). Chichester: John Wiley \& Sons Ltd.

Bancel, F., \& Mittoo, U. (2004). Cross-country determinants of capital structure choice: A survey of European firms. Financial Management, 33(Winter), 103-132.

Bevan, A. A., \& Danbolt, J. (2002). Capital Structure And Its Determinants In The UK-A Decompositional Analysis. Appl. Financ. Econ., 12, 159-170. http://dx.doi.org/10.1080/09603100110090073

Booth, L., Aivazian, V., Demirguc-Kunt, A., \& Maksimovic, V. (2001). Capital Structures In Developing Countries. J. Finance, LVI(1), 87-130. http://dx.doi.org/10.1111/0022-1082.00320

Bradley, M., Jarrell, G. A., \& Kim, E. H. (1984). On The Existence of An Optimal Capital Structure: Theory And Evidence. Journal Of Finance, 39, 857-880. http://dx.doi.org/10.1111/j.1540-6261.1984.tb03680.x

Brounen, D., De Jong, A., \& Koedijk, K. (2006). Capital Structure Policies In Europe: Survey Evidence. Journal Of Banking And Finance, 30, 1409-1442. http://dx.doi.org/10.1016/j.jbankfin.2005.02.010

Chakraborty, \& Indrani. (2010). Capital Structure In An Emerging Stock Market: The Case of India. Research In International Business And Finance.

Chen, J. J. (2004). Determinants of capital structure of Chinese-listed companies. J. Bus. Res., 57, 1341-1351. http://dx.doi.org/10.1016/S0148-2963(03)00070-5

Cheng, S. R., \& Shiu, C. Y. (2007). Investor Protection and Capital Structure: International Evidence. Journal Of Multinational Financial Management, 17, 30-44. http://dx.doi.org/10.1016/j.mulfin.2006.03.002

Chui, A. C. W., Lloyd, A. E., \& Kwok, C. C. Y. (2002). The Determinants Of Capital Structure: Is National Culture A Missing Piece To The Puzzle? J. Int. Bus. Stud., 33(1), 99-128. http://dx.doi.org/10.1057/palgrave.jibs.8491007

Deesomsak, R., Krishna, P., \& Gioia, P. (2004). The Determinants Of Capital Structure: Evidence From The Asia Pacific Region. Journal Of Multinational Financial Management, 14(4-5), 387-405. http://dx.doi.org/10.1016/j.mulfin.2004.03.001

Delcoure, N. (2007). The Determinants of Capital Structure in Transitional Economies. International Review of Economics and Finance, 16, 400-415. http://dx.doi.org/10.1016/j.iref.2005.03.005

Fattouh, B., Pasquale, S., \& Laurence, H. (2005). Capital Structure In South Korea: A Quantile Regression $\begin{array}{llll}\text { Approach. Journal Of Development Economics, } & 76,\end{array}$ http://dx.doi.org/10.1016/j.jdeveco.2003.12.014

Fawad, A., Haq, J. U., Nasir, R. U., Ali, M., \& Ullah, W. (2011). Extension of determinants of capital structure: Evidence from Pakistani non-financial firms. African Journal of Business Management, 5(28), $11375-11385$.

Friend, I., \& Lang, L. (1988). An Empirical Test Of The Impact Of Managerial Self-Interest On Corporate Capital Structure. J. Finance, 43, 81-271. http://dx.doi.org/10.1111/j.1540-6261.1988.tb03938.x 
Gaud, P., Jani, E., Hoesli, M., \& Bender, A. (2005). The Capital Structure Of Swiss Companies: An Empirical Analysis Using Dynamic Panel Data. Eur. Financ. Manage., 11(1), 51-69. http://dx.doi.org/10.1111/j.1354-7798.2005.00275.x

Giannetti, M. (2003). Do Better Institutions Mitigate Agency Problems? Evidence From Corporate Finance Choices. Journal Of Financial And Quantitative Analysis, 38, 185-212. http://dx.doi.org/10.2307/4126769

Graham, J., \& Harvey, C. (2001). The theory and practice of corporate finance: Evidence from the field. Journal of Financial Economics, 60, 187-243. http://dx.doi.org/10.1016/S0304-405X(01)00044-7

Greene, W. H. (2003). Econometric Analysis (5th ed.). Upper Saddle River: Prentice Hall.

Gujarati, D. N. (2003). Basic Econometrics (4th ed., pp. 636-653). London: Mc Graw Hill Companies, Inc.

Hall, G., Hutchinson, P., \& Michaelas, N. (2004). Determinants Of The Capital Structures Of European Smes. Journal Of Business Finance And Accounting, 31, 711-728. http://dx.doi.org/10.1111/j.0306-686X.2004.00554.x

Harris, M., \& Raviv, A. (1991). The Theory of Capital Structure. Journal of Finance, XLVL(1), 297-355. http://dx.doi.org/10.1111/j.1540-6261.1991.tb03753.x

Hausman, J. A., \& Taylor, W. E. (1981). Panel data and unobservable individual effects. Econometrica, 49, 1377-1398. http://dx.doi.org/10.2307/1911406

Hodder, J. E., \& Senbet, L. W. (1990). International Capital Structure Equilibrium. The Journey of Finance, 45, 516-1495.

Hsiao, C. (1999). Analysis of panel data. Cambridge: Cambridge University Pres.

Huang, G., \& Song, F. M. (2006). The Determinants Of Capital Structure: Evidence From China. China Economic Review, 17, 14-36. http://dx.doi.org/10.1016/j.chieco.2005.02.007

Jensen, M. C., \& Meckling, W. H. (1976). Theory Of The Firm: Managerial Behavior, Agency Costs and $\begin{array}{llll}\text { Ownership Structure. Journal Of Financial Economics, 3, 305-360. } & \text { 3, }\end{array}$ http://dx.doi.org/10.1016/0304-405X(76)90026-X

Kovenock, D., \& Phillips, G. M. (1997). Capital structure and product market behavior: An examination of plant exit and investment decisions. Review of Financial Studies, 3, 767-803. http://dx.doi.org/10.1093/rfs/10.3.767

Lee, S., \& Woo, G. K. (2009). EVA, Refined EVA, MVA, or Traditional Performance Measures for the Hospitality Industry? International Journal of Hospitality Management, 28(3), 439-455. http://dx.doi.org/10.1016/j.ijhm.2009.01.004

Mahajan, A., \& Tartaroglu, S. (2008). Equity Market Timing And Capital Struture: International Evidence. Journal Of Banking \& Finance, 32, 754-766. http://dx.doi.org/10.1016/j.jbankfin.2007.05.007

Marsh, P. (1982). The Choice Between Equity And Debt: An Empirical Study. J. Finance, 37, 121-144. http://dx.doi.org/10.1111/j.1540-6261.1982.tb01099.x

Mene'ndez, E. J., \& Go'mez, S. (2000). Product and labour markets as determinants of capital structure in a medium-sized economy. IV Foro de Finanzas de Segovia, Segovia.

Modigliani, F., \& Miller, M. H. (1958). The Cost Of Capital, Corporation Finance and The Theory of Investment. American Economic Review, 48, 261-297.

Myers, S. (1977). Determinants Of Corporate Borrowing. Journal of Financial Economics, 5, 147-175. http://dx.doi.org/10.1016/0304-405X(77)90015-0

Nachane, D. M. (2006). Econometrics: Theoretical Foundations and Empirical Perspectives. Oxford University Press.

Ozkan, A. (2001). Determinants Of Capital Structure And Adjustment To Long Run Target. J. Bus. Finance Account, 28, 175-98. http://dx.doi.org/10.1111/1468-5957.00370

Pandey, I. M. (2001). Capital Structure and the Firm Characteristics: Evidence from an Emerging Market. IIMA, 10(4).

Pandey, I. M., Chotigeat, T., \& Ranjit, M. K. (2000). Capital Structure Choices In An Emerging Capital Market: Case Of Thailand. Management And Change, 4(1), 1-14.

Rajan, R. G., \& Zingales, L. (1995). What Do We Know About Capital Structure? Some Evidence From 
International Data. J. Finance, 50, 1421-1460.

Song, J., \& Philippatos, G. (2004). Have We Resolved Some Critical Issues Related To International Capital Structure? Empirical Evidence From The 30 OECD Countries. Working Paper, University Of Tennessee.

Sun, H., \& Parikh, A. (2001). Exports, Inward Foreign Direct Investment (FDI) and Regional Economic Growth in China. Regional Studies, 35(3), 187-196.

Tang, C. H. H., \& Soocheong, S. J. (2007). Revisit To The Determinants Of Capital Structure: A Comparision Between Lodging Firms And Sofware Firms. Hospitality Management, 26, 175-187. http://dx.doi.org/10.1016/j.ijhm.2005.08.002

The Financial System And Banking Sector In Turkey. (October 2009). İstanbul, The Banks Asscociation of Turkey. Retrieved from http://www.tbb.org.tr

Titman, S., \& Wessels, R. (1988). The Determinants Of Capital Structure Choice. Journal Of Finance, 43, 1-19. http://dx.doi.org/10.1111/j.1540-6261.1988.tb02585.x

Tunay, K. B. (2009). Türk Bankacılık Sektöründe Rekabet Ve Kırılganlık. Bankacılar Dergisi, Sayı 68.

White, H. A. (1980). Heteroscedasticity-Consistent Covariance Matrix Estimator And A Direct Test For Heteroscedasticity. Econometrica, 48(4), 817-838. http://dx.doi.org/10.2307/1912934

Wooldridge, J. M. (2002). Econometric Analysis Of Cross Section And Panel Data. Cambridge: The MIT Press. Yafee, R. (2003). A Primer for Panel Data Analysis. Connect: Information Technology at NYU, (Fall), 1-11.

Note

Note 1. VIF > 10 may be multicollinearity problem (Nachane, 2006; Lee ve Kim, 2009). 